\title{
'Dynasty' in modern German intellectual history: many concepts, or none?
}

Dina Gusejnova

Department of International History, LSE, London, United Kingdom

Dina Gusejnova, Department of International History, The London School of Economics, Houghton St, Holborn, London WC2A 2AE

d.gusejnova@1se.ac.uk 


\section{'Dynasty' in modern German intellectual history: many concepts, or none? ${ }^{1}$}

This article analyses the conceptual use of terms describing dynastic rule in modern German thought. It examines three topics in which the term 'dynasty' specifically appears: with reference to the non-European empires, European states, and the future of democracy in Germany around 1918. Looking at a range of key thinkers with Max Weber's work as a central reference point, it engages with the question why, despite this wide usage, the influential dictionary Geschichtliche Grundbegriffe does not cover any term describing hereditary rule. The conclusion provides a range of possible explanations for the absence.

Keywords: dynasty; Begriffsgeschichte; conceptual history; social history; genealogy; Reinhart Koselleck; Wilhelmine Germany; Max Weber; Grimm dictionary; modernity


colloquially means a 'succession of rulers of the same line or family'. ${ }^{1}$ Like other European languages, German has a range of words to describe the notion of dynastic power. In the first instance, these are words which have a Germanic origin, such as Geschlecht (genus, tribe), Geblüt (blood lineage), Erbadel (hereditary nobility), and Haus (house). ${ }^{2}$ The Greek term Dynastie and its derivatives, dynastisch, Dynastenherrschaft, are also used in German, but less common. Given the prominence and longevity of hereditary power in the political and intellectual history of Europe, it is surprising that the eminent German dictionary of social and political concepts,

\footnotetext{
${ }^{1}$ I am grateful to Martial Staub, Ilya Afanasyev, and Milinda Banerjee for their thoughtful suggestions on drafts of this paper. I have also benefited from discussions of materials from this paper at several seminar series and conferences, including the German Studies Association (Kansas City, 2014) and the IHR Imperial and World History Seminar (KCL, 2014), the German History Society (London, 2015), the Political Thought and Intellectual History Seminar (Cambridge, 2016), 'The Modern Invention of "Dynasty"' (Birmingham, 2017) and 'Elites and Democracy in Modern Political Thought' (Cambridge, 2017).
} 
Geschichtliche Grundbegriffe [GG] has no entry on 'dynasty', nor its related vernacular concepts. The dictionary project assembled by Reinhart Koselleck and his colleagues sought to identify words which had the function of a theoretical understanding of social reality, i.e. terms which were not just 'indicators' of their social and political circumstances, but also 'factors' in their own right in their development. ${ }^{3}$ It seems that some variant of 'dynasty' should, theoretically, fit the bill. Was there really no German concept of dynasty in this sense?

In this paper, I hope to engage with this question by trying to understand how Weber and his contemporaries described hereditary power, and why they made the choices that they made. I will be looking at a small group of intellectuals which dominated the intellectual culture the Kaiserreich, including people belonging to the Weber circle, but also Friedrich Meinecke, Georg Simmel, and Theodor Mommsen. ${ }^{4}$ Revisiting their discussions of words related to hereditary power, I propose to explore to what extent the range of their usages of words related to conceptions of hereditary power amount to a concept of dynasty. In this context, I shall distinguish between banal and theoretical uses of words capturing the hereditary transmission of power. The distinction between words, concepts and conception is a subject of long-standing philosophical debate which pits two philosophies of perception against each other, the empiricist and the rationalist view. ${ }^{5}$ According to the empiricists, humans are adjusting their categories of perception to their experience of phenomena. For the rationalists, it is significant that humans are born with innate categories and a capacity to sort their perception of phenomena into these. For the purposes of my analysis, however, I will refrain from engaging in the debate on the origin of concepts themselves, but merely focus on the linguistic level of conceptual usage. Here, I shall differentiate between the use of words in a banal or colloquial sense on the one hand, and in a theoretical and analytic sense, on 
the other. For instance, one type of intellectual intervention uses words to describe different disparate phenomena, while another type of intervention can use a word in a more instrumental sense, to synthesise and compare classes of such phenomena. In the former case, I will speak of conceptions, notions, or banal word usages. To the latter case, I will ascribe the term 'concept'. One hypothesis is that frequently, in German political thought, vernacular terms are used for banal descriptions of phenomena, whereas notions with foreign etymology such as Dynastie are used to summarise, synthesise and compare.

Another distinction I propose is to make is that between conscious conceptual usage by one or several speakers, as it happened with Weber's coinage of the Erbcharisma, and the existence of a topic, or a family of words, which can be ascribed to a community of speakers but which does not feature a clear tag or label. By examining co-occurring words in contexts, one can identify the existence of topics in intertextual analysis which establish how likely it is that a certain community of speakers will use a certain word to describe a phenomenon relevant to this topic - and also, identify when a comparatively new term enters the field or disappears from it over time. Such a co-occurrence of different words should be differentiated from a conscious use of words to draw categorical distinctions. In other words, three speakers might be aware that they speak about the same topic when they discuss Geschlecht, Haus and Dynastie, but unless they consciously summarise these notions under a term such as Weber's Erbcharisma, I cannot ascribe to them the possession of a concept of hereditary rule. In this case, Koselleck and his colleagues might have been right to omit the words altogether. I would also like to add, towards the end of this piece, that a topic of discussion in the above sense can therefore include discourse in literary fiction, and it can also be observed through non-linguistic symbolic practice such as the collection of 
particular objects and material culture more generally. It is not insignificant that one of the branches of the foundational skills for historians which is particularly established in Austrian universities, the so-called Realienkunde, evolved around an engagement with the study of insignia and material objects of power, to which representations of dynastic power also belong. ${ }^{6}$ However, my main point of reference is nonetheless the ideal typical notion of a concept, i.e. a word which is operationalised in arguments.

A brief overview of a range of historical dictionaries suggests initially that the omission of 'dynasty' from $G G$ might have been justified, at least insofar as the methodology of the $G G$ was concerned. The Grimms' dictionary has a range of Germanic terms to describe hereditary power, but no entry on 'dynasty', except in relation to lineages of gods, Götterdynastien. ${ }^{7}$ The term also remains absent from successive editions of a range of widely read dictionaries of political thought and theory, such as the Deutsches Staats-Wörterbuch and the Handwörterbuch der Staatswissenschaften. ${ }^{8}$ On the other hand, the term does appear in more general dictionaries produced in the mid-nineteenth century, such as Herders ConversationsLexikon or the Damen-Conversations-Lexikon. ${ }^{9}$

Before focusing on the Weber circle, and to supplement the review of dictionaries, I propose to take a cursory look at the writings of some of the major thinkers in modern German thought and fiction reveals more details to the relationship between different words describing hereditary power in German. In modern German thought as in other European languages, 'dynasty' had acquired a more neutral and even banal meaning, describing the power or domination of a ruling lineage, and also the periods of time when such family units were in power. The means of conferring power from generation to generation can be material or ideological and involve cultural practices such as primogeniture and the cultivation of lineages. ${ }^{10}$ In this sense, one could surmise that 
Dynastie was a foreign word but had lost the status of a concept which it had enjoyed in ancient political thought.

The term of Greek origin, Dynastie, is widely used in the Enlightenment era to describe non-European and oriental societies, while conceptions of hereditary rule are usually expressed using words such as Geschlecht and Erbadel. Often the entire range of words describing notions of dynastic power is used pejoratively. Immanuel Kant used the term hereditary nobility [Erbadel] to effectively provincialize dynastic forms of power in his own political thought, connecting his critique of both French and Prussian dynastic rule to a longer tradition of European republicanism. ${ }^{11}$ Subsequently, the German Philhellenists and Orientalists - two fields of academic research which had evolved from theology -- proved remarkably disinterested in the notion altogether. ${ }^{12}$ The Romantic poet Georg Wilhelm Friedrich Schlegel wrote this satirical epigram on the word dynasty in the form of a riddle subsequently titled 'Change of dynasty in the philosophical schools'.

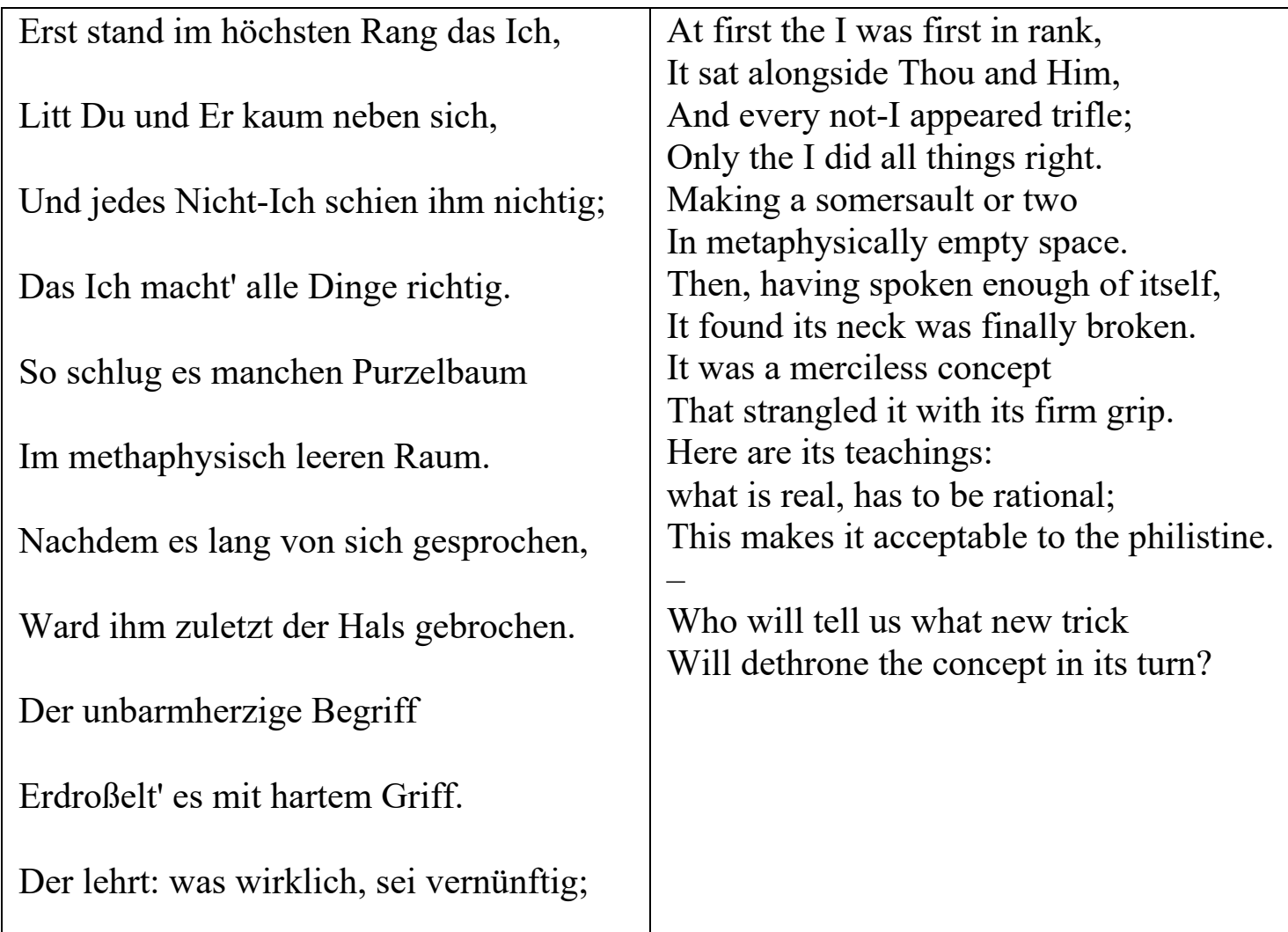




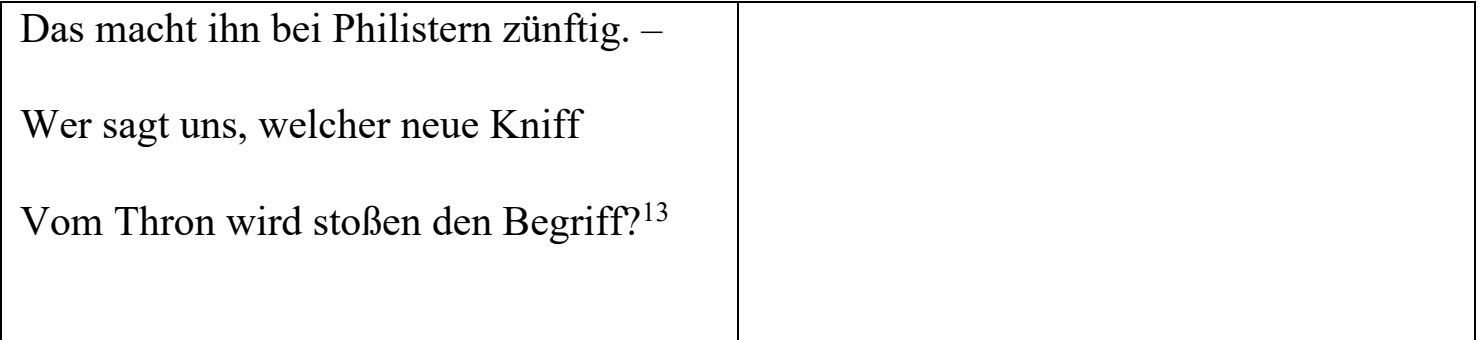

The existence of this epigram suggests that Schlegel appealed to a prevailing understanding of 'dynasty' in the context of a hegemonic abuse of power - even though in this case, the domination is intellectual rather than political. In his writings on religion, Schlegel's rival Hegel, whose ideas are possibly being mocked in the poem, used the term dynasty sparingly and with reference mostly to the non-European lineages. ${ }^{14}$ One significant exception, however, was the Philosophy of History, where he discussed dynasties in the plural, comparing their presence in global perspective. In Asia, progress was halted by the prevalence of dynastic succession as a principle of political legitimacy. In the Holy Roman Empire, just as in the non-European empires in Asia and the Middle East, he argued, dynastic forms of power were based on a set of 'private rights' [Privatrechte], which attained 'momentary' status as state law but ultimately precluded the emergence of statehood. Such a state as the Holy Roman Empire of the Roman Nation, with is institution of an elective emperor, had a family and not an institution as its centre of gravity. 'Because Germany was an elective empire, it never became a state, and for the same reason Poland has left the ranks of independent states. ${ }^{15}$ Having covered dynasties in China, in the Arabic world, in Japan, and in medieval and early modern Europe, Hegel's account of 'dynasties' in the plural ends with the French Revolution, when the suspicions towards the ruling dynasty ['die Dynastie war verdächtig, weil sie die vorhergehende Macht verloren' - 'the dynasty [of the Bourbons] evoked suspicions on account of having lost power') radicalised the course of the French Revolution and made the return of sovereignty from the monarch to the people necessary. ${ }^{16}$ 
Friedrich Nietzsche, throughout his work, made allusions to dynasties but effectively dissolved the notion in sarcastic, playful, or otherwise counterfactual notions of lineage and genealogy. ${ }^{17}$ The idea of dynasty was represented in the culture of Wilhelmine Germany through such works as the historical tableaux of visual artists Anton von Werner, Karl Theodor von Piloty; in Austria, by Hans Makart, which used representations of dynasties to depict the German nation in one case, and the unity of the Habsburg subjects in the other. These paintings prompted Nietzsche to write in the Untimely Meditations that 'we are all suffering from a consuming fever of history and ought at least to recognise that we are suffering from it.. ${ }^{18}$ Perhaps the clearest critical perspective on the status of the dynasty as a concept of power can be seen in Nietzsche's engagement with ideas of genealogy and with the work of Wagner. ${ }^{19}$ Initially fascinated by Wagner, Nietzsche saw the new mythmaking of Wagner's ring cycle with its dynasty of Gods as something pathological. Wagner himself did not use the term dynasty but Geschlecht in works such as the libretto of the Götterdämmerung or the account of the Nibelungen saga - and there, the giant Fasolt appears as a critic of the Gods' hegemony. ${ }^{20}$

It appears that the range of contexts in which 'dynasty' was used in German before the twentieth century, when Max Weber coined the term Erbcharisma, was much narrower than his concept suggests, and more closely linked to despotism than to hereditary forms of domination. ${ }^{21}$ This word was his own creation, and as such did not meet the criteria of a concept in Reinhart Koselleck's sense - as something which is 'not only an indicator' but is excavated from the actual use by a living society, not one scholar. ${ }^{22}$ Could it be that Weber's ideal type therefore only underlined the fact that other German speakers used the above notions merely in a banal, not a theoretical sense? And how might it be possible technically to study an absent concept? 
The idea of studying the supposed absence of a concept has a history in the critical study of ideologies, and as such promises to reveal something of the 'horizons' and 'boundaries' of a society in much the same way as the presence of concepts. As Stuart Hall had once suggested when speaking of 'ideology' as an absent concept in American political thought, reconstructing the circumstances and reasons for the absence of a concept provides new insights into the particular ideological framework within which an intellectual community operated. ${ }^{23}$ For similar reasons, William Sewell has made the exploration of 'neglected' areas of study a subject of critical historical research. ${ }^{24}$ This article suggests that the exploration of an absent concept can itself be revealing of a particular ideological constellation which emerged in late imperial Germany and culminated in particular reflections on modernity in general and, in 1918, on Germany's future in particular.

The authors whose work I now want to examine in more detail formed a rather small network, but one which was highly influential not only in the German establishment at the time, but also subsequently in European and global contexts. They published in the same venues and shared much of the same cultural code. They also shared some broad political attitudes. They disliked Wilhelm II and the pomp and circumstance of the Hohenzollern-dominated state, even though their political intuitions about the alternatives to this society differed widely. Each in their own domain literature, social, political or economic theory - developed a particular language of detached irony which enabled them to speak of elites in an almost value-free manner. Yet, they were caught between being disenchanted with old princely rule and never fully enchanted by democracy. 
For a long time, intellectual historians have been chiefly interested in the political thought of the Kaiserreich for two reasons: first, in order to examine the darker lineages of modern German political thought and the failure of what Fritz Ringer influentially called the 'German Mandarins'; secondly, as a repository for value-neutral concepts in modern social and political theory, particularly, the understanding of modernity, which emerged in German intellectual communities at this time. ${ }^{25}$ But the intellectual output of Wilhelmine Germany can also be of interest in its own right, as a window on the intellectual experiences of modernity of a specific community which later became very influential globally. ${ }^{26}$ Recently, historians such as Edith Hanke have drawn attention to the global authority of Max Weber and his circle, which was reinforced by his role as a cognisant witness of an historical turning point that included imperial decline and revolution. In this sense, his circle can serve as a case study not only for understanding bourgeois society, but also the self-image of the bourgeois in wider contexts. ${ }^{27}$

The intellectual community associated with the journal Archiv für Sozialwissenschaft und Sozialpolitik provides an insight into the mood and mentality of a society which is otherwise known for its outward success. ${ }^{28}$ Retrospectively, to us, this period is known as the Founder's Era - the years following the 'foundation' of the German Empire in 1871 on the back of the Franco-Prussian war. This term Gründerzeit - is essential in today's real estate market in Germany, rather like the word 'Georgian' is in British property sales. ${ }^{29}$ At this time, the foundations were made for much of Germany's political and intellectual capital as well, which various people had to access after 1945: politicians trying to rebuild German democracy under allied occupation, like Theodor Heuss; but also, democratic theorists, particularly in the US, who tried to reaffirm the vows of the troubled marriage of liberalism and democracy, 
like C. Wright Mills. In fact, however, people of the Kaiserreich were often plagued by the fear of decline and loss, and the topic of hereditary rule did provide a foil for such thoughts. As less well-known émigré historians and witnesses of the time, like Hans Rosenberg, insisted, this was also a time of great anxiety and uncertainty, and these sentiments can also be captured by examining their conceptual production. A shift in the uses of the term 'dynasty' first crystallised in a period which was known as the first Great Depression, which lasted from 1873 to 1896 . As such it was 'not purely an economic phenomenon, but also a psychic one', which contemporaries described with a maritime metaphor - Flaute, a lull, a windstill period in which no sailing is possible. ${ }^{30}$ The liberals of the 1848 generation were no longer radical, and the social democrats were beginning to be recognised as the established party on the left. At the same time, the German middle class gained confidence of its own powers thanks not least to their economic importance on a global stage. As one of Theodor Fontane's characters, the educated bourgeois Marcell, put it, from their point of view, it was 'easier to penetrate a Duke's family than a bourgeois one'. ${ }^{31}$

The political backdrop for the prominence in the use of the term 'dynasty' in the international context of European history was the so-called Caesarism and dynastic posturing associated particularly with the figure of Napoleon III, whose demeanour liberals and socialists alike frequently contrasted with that of the older European aristocratic families. ${ }^{32}$ Conversely, in Austria-Hungary, the period is a time when the stability of the ruling crown is threatened by the rise of new secessionist movements and demands for compromise.

There is also a sociological dimension, and the cultural practices of a particular milieu, which can help illuminate the increasing appeal of a 'dynastic' imaginary. Conceptual production in modern German - both in Wilhelmine Germany and in 
Austria-Hungary -- was a remit of self-consciously bourgeois thinkers, and yet precisely in order to articulate how this 'middle-classness' or Bürgerlichkeit differed in terms of legitimacy from that of other social strata, the term 'dynasty' became useful. ${ }^{33}$ One can catch an impression of this use in Thomas Mann's second novel, Royal Highness, published in Germany in 1909 (but not translated into English till 1916), which is set in a fictionalised version of one minor German principality, Grimmburg. The prince of what Mann calls with his typical sarcasm Grimmburg's 'Dynastenfamilie' is about to be rescued from decline by marriage to the daughter of a rich entrepreneur called Spoelmann, who happens to own a large glass collection. I suggest that this collection is worth examining in some more detail as a kind of metonymical discussion which parallels thoughts about hereditary power in Germany around 1900. It is also an important source for accessing how a society can relate to a subject not only conceptually and linguistically, but also through material culture.

Like a modern Kunstkammer, Spoelmann's collection itself is organised by periods, whereby

in one corner of the room were the earliest luxury designs of the arts and crafts industry, complete with the heathen products of the occident and the orient of all time periods. This was then followed by vases and beakers richly adorned with wreaths and other decorations, coming from the Venetian blow-pipes and including costly pieces from the Bohemian workshops, German tankards, glasses depicting guilds and the elector princes, with the grotesque likeness of animals and comic figures, etc. etc. There follows an even longer list of crystal cups and 'ruby-coloured' Holy Grails. ${ }^{34}$ 
The material presence of such symbolic items in the art collections of established bourgeois families of late imperial Germany - which we see with the eye of an impartial spectator but also through the eyes of the prince of Grimmburg, Klaus Heinrich -echoed the preoccupation with imperial status symbols among the aspirational bourgeoisie, but also provincialized the theme of dynasty in this context. It is not surprising that Thomas Mann used the glass collection as one of the crucial settings to show how a feeble and declining royal duchy seeks to maintain its status by 'marrying into' a vigorous bourgeois family. In Thomas Mann's novel, as in Germany of his time, it was the bourgeoisie that was 'collecting' and amalgamating elements of the aristocracy, if you like, rather than the other way around. In the novel, Spoelmann is about to marry off his daughter to prince Klaus Heinrich, the feeble leader of the declining duchy of Grimmburg. Like the imperial tankard which makes it into the collection of a bourgeois family, one could say that the prince himself is to become a sort of collector's item.

Mann's novel reflected not only the intellectual appropriation of hereditary charisma, but also the social reality of bourgeois collecting. In Germany around the year 1900, most serious glass collections included a certain type of tankard, produced in the German empire around the sixteenth and seventeenth century, which were called Reichsadlerhumpen. A brief look at the actual social history of glass collection will allow me to contextualise this point as something that is not just a literary phenomenology. One famous collector was Lüttich-born bibliophile William Davignon (1867-1924), a resident of Leipzig. After his death in 1924, the GRASSI Museum für Angewandte Kunst acquired his collection of art and crafts objects. The tankards, which could hold up to four litres of wine or beer, were, by the mid-16th century, among the most popular drink containers. The cylinder-shaped glasses were shaped with the 
heraldic symbols of the Holy Roman Empire of the German Nation, with its doubleheaded eagle with spread wings, on which every feather represented, in four groups (called Quaternionen) 56 heraldic symbols of the estates, lands, and cities of the Reich. Up to 1600 , a crucifix typically adorned the breast of the eagle. Later, Jesus was replaced with the imperial orb [Reichsapfel], and occasionally, with the portrait of Emperor Leopold (1658-1705). ${ }^{35}$ Other such tankards can be found in arts and crafts collections across Europe, including, for example, the British museum. We can see how the images first included a representation of power which was overwhelmingly focused on Jesus as the heart of authority. This was followed by the heraldic symbols of the estates, lands, and cities of the Reich. The nation, in other words, was shown as fragmented yet recognisably held together by a common eagle. In the Holy Roman Empire of the German Nation, Georg Simmel had argued, the power of dynasties was superseded by the institution of service or servitium, whereby all the members of the commonwealth were connected amongst each other and with the King. ${ }^{36}$

Against this background, intellectuals such as Georg Simmel, Max Weber, and Joseph Schumpeter - members of an intellectual community whose visible outputs were found in overlapping journals and edited volumes -- were intensely preoccupied with understanding hereditary power in this period, and they also did use 'dynasty' in this context. $^{37}$ There are broadly three ideal types of power for which German intellectuals deployed the notion of 'dynasty' as an explanation, and which I will discuss below in more detail. The first was the idea of dynasty as an institution which prevails in nonEuropean - particularly, Asian and Middle Eastern -- empires or imperial types of hegemony. This was the field of study where the word 'dynasty' was most frequently used to describe political power. A second domain within which conceptions of dynastic power were discussed was in relation to European state formations, from the Germanic 
and Celtic tribes to modern monarchies. Here, dynasty could be at best identified as the common topic among a rich vocabulary reflecting the power of, and by, inheritance. A third area of meaning with which German thinkers imbued the notion of dynasty had to do with democracy. Examples include families, guilds, and parties, in opposition to the hegemony of rulers or other dominant groups. After the discussion of these three notions, I propose to examine the specific usage of the term 'dynasty' in the political contexts of late imperial Germany and contextualise this usage in broader histories of German and European political thought.

\section{Dynasty and the study of empires}

The historical and comparative study of empires was one of the growing areas of German scholarship in this period. Scholars teaching at leading German institutions in the Wilhelmine period developed the field of comparative global history, while remaining divided over the kind of emphasis that was appropriate. For instance, there were methodological as well as political conflicts over the terms of such a history, and the extent to which what would today be called a history from below, or local and regional history, should be part of such an endeavour, as evidenced in the Lamprechtstreit. ${ }^{38}$ The new fields of historical sociology and economic history also added to the debate about the nature of global comparisons. Works on universal and global history also experienced something of a renaissance among more popular writers who were not part of the academic establishment- a phenomenon which culminated in the work of Oswald Spengler. ${ }^{39}$ As in other European languages, in all these fields of research, the word 'dynasty' was used to describe lineages and clans, particularly with respect to the non-European empires, such as the Seleucid dynasty or the Ming dynasty, as well as the periods corresponding to their rule - disregarding the existing differences 
between the hereditary regimes in each setting. The question is whether theorists ascribed any conceptual value to these words beyond their banal signification.

Weber himself drew on his own as well as secondary studies of dynastic rule in ancient China, Egypt, Mesopotamia, including extensive discussions of the nature of familial power in these societies. ${ }^{40}$ In his account of China, Weber emphasised the power of the dynasty to unite an empire which was under threat of fragmentation. ${ }^{41}$ In Egypt and in China, Weber remarked, dynastic rule was embedded in a web of other cultural markers, such as the belief in the divine origin of the ruling lineage alongside its entrenchment in local settings such as the choice of the capital city, which changed with each changing lineage. ${ }^{42}$ What Weber was most interested in was the comparison and the transformation of charismatic authority in global contexts and across long periods. According to him, charismatic authority shifted from the beliefs in the special powers of each ruling emperor to the belief in the charisma of the clan or lineage as such. This is where he saw the greatest difference between the oriental and western conceptions of power. In a society like ancient China, the charisma of the group was always primary. There were some elements of this in early medieval western Europe, Weber conceded, but on the whole hereditary charisma was much more loose there and always left more room for 'parvenus' ${ }^{43}$ At the same time, ironically, in China, where he had claimed earlier, the family lineage was always the primary unit of reference, one of the most powerful dynasties, the Han, had been founded by a 'parvenu'. Elsewhere, dynasties were shown to thrive through alliances with educated elites which were bred rather than born. By the fourteenth century, in order to preserve their power, Weber argued, the Ming dynasty cemented its rule through the creation of a loyal and thoroughly educated bureaucracy of literati - the Mandarins. ${ }^{44}$ 
In his studies of ancient Judaism and of ancient Rome, Weber highlighted the absence of dynastic thought in the religion of ancient Judaism and in the political culture of ancient Rome. 'Jahwe was never the god of the dynasty in the way that Assur, Marduk or Nebo had been, but had always been a god of the Israelite confederates [der israelitischen Eidgenossen]'. This did not prevent the dynasties and kings from enlisting Jahwe's prophets in their service, however. ${ }^{45}$ In a similar fashion, Weber contrasted the importance of the use of adoption among the Roman emperors with the Hellenistic traditions of strict blood lineages. ${ }^{46}$ Where dynasty did feature in late Roman society, it also contributed to its decline: according to Weber, the Roman world veered towards disintegration when its army and bureaucracy became increasingly dynastic. Late imperial Rome was a 'military-dynastic regime' and in this capacity, he claimed it had even been influenced by the Hellenistic-Egyptian example of this type. This meant that the old model of administration which centred on the polis and its citizens no longer applied. ${ }^{47}$

The political dimension to Weber's use of dynasty can be understood better in its broader intellectual context. For instance, on the political right, the classicist Eduard Meyer, in his five-volume study of global ancient societies, initially used the notion of dynasty in a very straightforward or banal sense, without actually introducing it. It was simply assumed in his discussion of the transition from ancient tribal societies to the civilizations of Babylonia and Assyria. ${ }^{48}$ The social significance he attributed to dynasties becomes clearer when we consider his coverage of the end of the ancient Egyptian polity. While each dynastic change entailed a revolution of sorts, it was the end of all dynastic power in the Middle East which, in Meyer's view, fragmented the nation and left it fractured and leaderless. After the end of dynastic rule their 'followed an epoch of small states $[$ Kleinstaaterei] [...] which however gave new peoples the 
space to develop their idiosyncracies freely. This enabled the space for the developments which we can observe later among the Phoenicians, the Israelites and the Greeks. ${ }^{` 49}$ Thus for Meyer, the ancient dynasties embodied and carried notions of national coherence as well as imperial hegemony, so that their disappearance also enabled the rise of new subaltern kinds of nationhood.

By contrast, for liberals who were closer to Weber's own, centrist views, nations and peoples everywhere existed independently from the dynasties ruling over them. Karl Lamprecht's method of world history avoided dynasties altogether. ${ }^{50}$ The eminent classicist Theodor Mommsen used the notion of dynasty to contrast Roman history and jurisprudence with contemporary oriental examples. ${ }^{51}$ His lectures on Roman jurisprudence featured the notion of dynasty as a comparative tool for analysing the Roman empire came out more clearly. ${ }^{52}$ In his judgment of Roman traditions and legacies, Mommsen shaped the views of the liberal intelligentsia in Germany and Europe of his time: his lively account read the past through the eyes of the present, and placed the community of Roman citizens with the term 'Bürgerschaft' - citizenry which resonated strongly with Bürgertum - bourgeoisie at the centre of his analysis. At the same time, Mommsen was also famous for his omission or perhaps even avoidance of the theme of empire. His published account of Roman History stopped just before the beginning of the imperial period - something subsequent interpreters attributed to the resistance of this liberal intellectual, who was steeped in the ideals of 1848 , to come to terms with the notion of 'empire' in Roman history. ${ }^{53}$ In Mommsen's reading, 'empire' was as much a temporal term, indicating the decline of the Roman Republic, as it was a type of state. Power itself was fragile and bound to morph into a new, pre-republican form of dynastic order - imperial succession. The notion of the Roman empire as a form of constitutional decline away from the Republic for him coexisted with and was not 
contradicted by the economic and territorial greatness of the Roman state. A key aspect of constitutional decline was the transformation of principles of rulership into those of dynastic inheritance --- something which throughout Roman history, Mommsen had associated with the more backward states of the Middle East, as well as the wilder Celtic tribes. Other scholars of empires concentrated on Muslim lineages and Islamic notions of legitimating rule. One of the founders of German Islamwissenschaft, Carl Heinrich Becker, analysed the place of dynasty in the wake of the collapse of the Ottoman empire. For him, the notion of dynasty helped explain the notion of a wider Muslim world, and the disunity that the abolition of the Sultanate and Khalifate was bound to bring about on the Ottoman successor states. ${ }^{54}$

In sum, when it comes to German studies of empire, German intellectuals used 'dynasty' freely, and they also often used it in a banal way, without definition or introduction. In many of these studies, the term 'dynasty' was used to describe a means of integrating disparate territories and communities. At the same time, in some of the above-mentioned works, dynastic allegiance and the dynasty's own power was also seen as an obstacle on the way of these societies' modernisation. But on the whole, it is noteworthy that much of this discussion did not feature any conceptual reflection on the meaning of the term, and indeed, often replaced the notion of dynasty with a range of other words. This contrasts rather greatly with the significant presence of this term, and related terms, in post-Second World War European social theory as well as historiography, from social theorists such as Maurice Halbwachs to historians such as Otto Gerhard Oexle and Jan Assmann. ${ }^{55}$

\section{Dynasty and the European states}


Dynastic succession of the ruling families was prominently associated with empires, especially, non-European empires. However, German historians and social theorists also discussed European examples of dynastic succession both within imperial and within smaller princely families. Some contexts where the notion of dynasty could applied to European history were histories of long lineages such as the Carolingians or the Capetians - although German medievalists preferred the term 'Geschlechter' over 'Dynastien' in this context. ${ }^{56}$ From the point of view of Germany's smaller princely states, liberal intellectuals juxtaposed the abuse of dynastic power by relatively 'young' but hegemonic dynasties such as the Prussian Hohenzollerns, or the neo-dynastic rule of Napoleon III, with the dynasticism of more moderate and small families.

According to Georg Simmel, the dynastic principle was one of the modes in which groups protect their interests from society at large ${ }^{57}$ A group, to follow Simmel, is a small society, which can range from a family to an association. What he was interested in is by what mechanism groups resist what he calls 'Vergesellschaftung', or becoming social. The protection of group power was anthropologically natural, according to Simmel, but it was not rational from a social point of view. Relying on the British Whig historian William Stubbs throughout, Simmel was fascinated by dynastic considerations as an explanatory factor in conflicts between parties (the Yorkists and the Lancastrians) in fifteenth-century England. Their attitudes could be compared to some of Germany's minor princes, who considered the ruling Prussian dynasty of the Hohenzollerns to be too young. ${ }^{58}$ Weber also analysed hereditary charisma when discussing the trade associations in the Middle Ages. ${ }^{59}$ The inability of groups to protect their heritage served as an interesting subject in Max Weber's work as an historical economist. ${ }^{60}$ Speaking counterfactually about the causes of Roman decline, he concentrated on the limited capacity of Roman craftsmen to transmit their skills to the new generation. The 
jurist Otto Gierke considered hereditary power in his study of primogeniture, the Fideikommiss, as an institution of old Germanic law which entrenched its anti-Roman structure - but without speaking of dynasties or dynastic succession. ${ }^{61}$

Yet another way of thinking about European power politics dynastically was in terms of the continuity of business interests through lineages. Family enterprises were part of the fabric of German industrial capitalism. As Joseph Schumpeter argued in the interwar period, their peculiar form of self-control secured the successful growth of capitalism in Germany.$^{62}$ It was self-evident that hereditary charisma was an aspect of their power and yet it is peculiar that none of the above thinkers chose the term 'dynasty' to describe such power, something which late twentieth-century popular culture seemed eager to do when speaking of American families like the Rockefellers. ${ }^{63}$ For instance, in Thomas Mann's Buddenbrooks, his 1901 saga of the rise and decline of a patrician dynasty, which was widely discussed in German society for decades before it brought him international fame with the Nobel Prize, the term 'dynasty' itself is conspicuously absent.

It is curious, given the presence but relative lack of prominence of the term dynasty among these self-consciously bourgeois thinkers, that the German 'Mandarins' themselves generated some of the best known dynasties in European cultural history but these were, arguably, dynasties in the modern European sense and not the tyrannical meaning of ancient authors. ${ }^{64}$ Notable examples include the Mommsens and the Cassirers. ${ }^{65}$ Another interesting aspect was that most theoretical models of dynasty produced by German thinkers thought of dynasties as constrained by male lineage and by national (or national-imperial) bounds. In their actual social experience, however, this was not the case. Family businesses often survived in the hands of 'representatives' 
of the family who were either female or foreign. This can be seen in the history of families such as the Krupps, and, in more global contexts, families such as the Rockefellers. ${ }^{66}$

The importance of dynasty for the history of the European state - as opposed to empires -- comes out most clearly in Friedrich Meinecke's work from the interwar period. ${ }^{67}$ According to Meinecke, it was a weakness of Friedrich II that his Anti-Machiavel, the work of political thought that had been co-authored by the Prussian King with Voltaire, did not make this sufficiently clear. The absence of a noble 'solidarity' with the entire 'aristocratic blood family of the Christian world' was, in Meinecke's view, a flaw of Friedrich's which left a glaring gap in German political thought. ${ }^{68}$ What is noteworthy was that the Anti Machiavel itself - written in French, of course -- never actually used the term 'dynasty' or 'dynastie' but spoke of an 'état hereditaire' instead. ${ }^{69}$

Unlike the study of non-European empires, where at least the use of the term, if not the concept of 'dynasty' looms large, in the history and theory of European states, German intellectuals did not leave much room for discussing the notion. If we use Weber's ideal type of 'hereditary charisma', a rather large family of other notions was more significant here, terms such as 'Stamm', 'Geschlecht', or 'Haus', but not dynasty. Friedrich Meinecke, in his analysis of German conceptions of nationalism and cosmopolitanism, argued that the German Romantics such as Schlegel used the term 'dynasty' to cancel out the mutual rivalries of individual monarch under an idealised, supra-monarchical empire. ${ }^{70}$ However, unlike contemporary French thinkers, the Germans were sceptical about the capacity of dynasties to lend their subjects the coherence of a nation. ${ }^{71}$ In Prussia, he argued, it took far more than the dynasty, but parliamentary institutions, to solidify the edifice of the state. 


\section{Dynasty and democracy}

The third associational field for the notion of dynasty in German intellectual communities to be explored is its connection to the present and future state of democracy. German intellectuals in this period were intensely preoccupied with the changing nature of political legitimacy in the face of economic as well as political modernization, and their own role within it. The three decades following the proclamation of the German Empire in Versailles in 1871 are known as the Gründerzeit [age of the founders] of a new great power state. This period coincided with a boom of commemorations of the ruling Prussian dynasty, the Hohenzollerns- including vastly unpopular projects such as the alley of Hohenzollern princes, humorously dubbed the Alley of Puppets by Berliners, completed in 1901, which included a parade of margraves and elector princes from the Hohenzollern dynasty since the 12 th century.

Most German liberals were far from enchanted by this new dynasticism - although the Hohenzollerns themselves used the terms 'Haus' or 'Ahnen' when speaking of their own power, rather than Dynastien. ${ }^{72}$ Friedrich Meinecke argued, channelling the views of other liberals, that Prussian power was characterised by a duality between the Berlin and Potsdam-based dynasty and the Prussian people who had sought representation at the Paulskirche in Frankfurt and greater national German sovereignty during the failed revolution. ${ }^{73}$ The end of the revolution in 1849 meant the hegemony of the Prussian dynasty over the other German dynasties. Nonetheless, Meinecke concluded in 1908, at least, the special position of the Prussian dynasty ended up fulfilling a positive function for the other German 'tribes' [Stämme]. ${ }^{74}$

In his Rektoratsrede of 1874, Theodor Mommsen committed himself most explicitly to the German national project but distanced himself from the dynasty. ${ }^{75}$ For Mommsen, 
the main threat to the Republic, already weakened by a disoriented and indebted aristocracy, came from either elements of degeneration in the 'wrong' application of the hereditary ideal within aristocratic milieus, or, from an abuse of hereditary powers in the democratic movement. Another liberal whose ideas had been formed in the revolutions of 1848 , Wilhelm Roscher, had coined the term 'Caesarism', to analytically vent his contempt for the kind of pseudo-dynasticism which Napoleon III - and, as it turned out, Wilhelm II -- pursued in his quest for power. ${ }^{76}$ Roscher identified dynastic succession as a last resort measure in times of crisis. As he put it, speaking of his contemporary France, when the 'crowd was incapable of liberty' it 'erected a dynasty'. ${ }^{77}$ Dynasty appeared here as something old, pre-modern, the last resort for a modern society facing its eclipse.

A major area of debate for Germany's liberals on the left and the right was the question of dynasty in relation to the power of political parties as well as the relationship between the succession of personnel and ideological continuity. In this context, the idea of dynasty as an aspect of party rule emerged as central. Here, too, German thinkers were inspired by historical material. Robert Michels' work on the sociology of modern parties is best known for his discussion of 'oligarchical' principles which supposedly prevail in most social organisations. However, he also has something interesting to say about the dynastic principle. He saw a danger in the persistence of the old regime. In nineteenth-century century France, he observed, the aristocratic families continue to comprise a significant element of the post-revolutionary national assembly. ${ }^{78}$ On the other hand, the revolutionary families themselves develop a dynastic and even an absolutist capacity ('le parti, s'est moi'), which he feared was an anthropological constant that had to be reckoned with. ${ }^{79}$ Considered with respect to the late nineteenth and twentieth-century century socialist parties (with the exception of the Bolsheviks and 
Fascists, whom he leaves out because of their statist character), Michels observed that the new socialist parties comprised notable elements of third or fourth generation activists who had their socialism 'in their blood' ${ }^{80}$ Socialism was not only a Milieuerscheinung but a hereditary kind of belief. Among the examples of political dynasties which he named were Marx, Longuet, and Liebknecht, whose children were active in the party. ${ }^{81}$ On the other hand, Michels also noted that the more radical elements of the socialist party comprised non-hereditary members, people who were in fact alienated or had estranged themselves from their social class or group to join the cause. As examples, he named Jews, but also people coming from affluent bourgeois families - including himself (his father was a Cologne trader) but also Friedrich Engels. For his psychological portraits of socialists who were estranged from their family origins, he also drew on memoirs such as Lily Braun's Memoiren einer Sozialistin. ${ }^{82}$

By contrast to Michels, intellectuals to the right of the liberal spectrum were less pessimistic. For instance, Friedrich Naumann, who is otherwise better known for his advocacy of the idea of Central Europe or Mitteleuropa, examined the question to what extent the future of German socialism would be negatively affected by dynastic principles. ${ }^{83} \mathrm{He}$ thought democracy and imperial dynasties were not only compatible but that the latter would help strengthen the former. His conclusion was that socialism may yet benefit from a kind of reformed dynasticism which would be identical to national interests.

\section{'Dynasty' as a critique of 'dynasts'}

Looking at the evolution of the meanings of dynasty from ca. 1880s to the 1900 s, we can see a range of conceptualisations of hereditary power which Weber has capaciously summarised under the term Erbcharisma. It is characteristic, however, that in order to 
express this notion, he did not use the word 'dynasty', nor the vernacular German words, but a neologism. This changed significantly in the year 1918 and 1919, however, when German public intellectuals not only began to use the word 'dynasty' more frequently, but also imbued it with more theoretical significance.

This polemical use of the concept of dynasty as a threat to democracy came out most clearly in the context of the debate on Germany's constitutional future in the wake of defeat in the First World War. ${ }^{84}$ First came Max Weber's advocacy of a republican form of government as a means to eschew political degeneration through dynastic power made the point most clearly. In his reflections on Germany's constitutional future, he argued that limiting dynastic forms of transmitting powers was a way of safeguarding the electability of office. ${ }^{85}$ In a series of articles on Germany's constitutional future, Max Weber warned sarcastically about the persistence of what he called 'dynastic feelings' [dynastische Gefühle] over the interests of the nation, ruling out dynastic regimes not only for the future of Prussia and Austria, which was a fait accompli, but also for Germany's smaller states. ${ }^{86}$ This was linked to the idea that dynastic power is integral to the type of authority held under the old regime which is opposed to the desirable forms of modernity. Germany's ruling dynasty had discredited the nation, and thus, in his view, 'only a government and an economy with a bourgeois [bürgerliche] structure will receive "credit". ${ }^{87}$ Germany's power prestige as a nation depended both literally and metaphorically on the credit granted to it by states such as Britain and the United States (Weber speaks of American credit above all). Weber does then entertain the danger that dynastic rule may yet return on the back of a democratic vote $-\mathrm{a}$ plebiscitary dynasty, but he dismisses it on account of all the German dynasties having discredited themselves [Diskreditierung der Dynastien]. ${ }^{88}$ Weber reached a wide liberal audience with his ideas thanks not only to the publication in the Frankfurter Zeitung, 
but also a series of talks on the subject which the delivered in several German cities. Speaking in Heidelberg at a meeting of the Progressive People's Party (Fortschrittliche Volkspartei), he made his own conviction of a republican form of state very clear, speaking of the 'imperial dynasty having discredited itself terrible as a consequence of the gravest political unfitness of the last holder of the throne'. 'furchtbare Diskreditierung der Kaiserdynastie infolge schwerster politischer Nichteignung des letzten Throninhabers.' What was needed was a dignified resignation not just of the Prussian dynasty but also, by extension, 'of dynasties as such' - but in such a way so as to avoid revolution. ${ }^{89}$ On another occasion, in Wiesbaden, Weber made more explicit how not just the Hohenzollerns but other dynasts had behaved inappropriately at the end of the war, seeking to broker separate deals on occasions such as the Peace of Brest Litovsk, where the Duke of Mecklenburg made claims to power over the former Russian province of Kurland. 'The dynasty has failed. But what should replace the old system?', he asked again and again, pushing his audience to accept the inevitability of a republican constitution with an 'antinationalist' form, which would mean truly acting in the interests of the nation. ${ }^{90}$ Elsewhere Weber also listed the misbehaviour of the King of Bavaria, whose separatism was widely discussed, as well as the reluctance of the King of Saxony to pick up the mess of the old regime..$^{91}$

After Weber, Friedrich Meinecke, in a proposal for Germany's constitution in 1919, spoke with a similar sense of disappointment when he distinguished between the "true, authentically Prussian system' which remained desirable and its 'degenerate form, gone out of control' ${ }^{92}$ If, in 1908, he had given the Hohenzollerns the benefit of the doubt, he now identified the place of the Prussian dynasty as a destructive hegemony which undermined the German nation. In order to articulate this change of attitudes, he again 
resorted to the term 'dynasty'. Meinecke who spoke with a sense of disappointment and yet less focus on dynastic failures when he distinguished between the 'true, authentically Prussian system' which remained desirable and its 'degenerate form, gone out of control'. ${ }^{93}$

In the writings of German liberals around 1918/1919, the word 'dynasty' became more frequent when they needed to distinguish the abuse of power by the Hohenzollerns from monarchy as a political regime. They came to see the Hohenzollerns as inimical not only to democracy but also to legitimate forms of monarchy. In their eyes, dynasties were connected to empires and to plebiscitary kinds of tyranny, even though in some cases, they could also facilitate the resistance to hegemonic imperial rule. In fact, on closer inspection, this usage of 'dynasty' in a pejorative sense comes closest to the use of the term in ancient political thought. For Aristotle, dynasty was a tyrannical type of oligarchy which, characteristically, exists both under a monarchical and a democratic regime, and in which 'men become supreme instead of the law'. ${ }^{94}$ In Plato's Laws, $\delta v v \alpha \sigma \tau \varepsilon i \alpha$ is the type of regime associated with forms of power prevalent in primitive societies such as the Cyclops or his contemporary barbarians. ${ }^{95}$ Characteristically, the discussion of this type of power in ancient European political thought had previously involved examples of societies foreign to them by virtue of their cultural or temporal distance, such as ancient Egypt, or the age of Homer. However, by 1918/19 it seemed to apply to Germany's own political situation.

\section{Some conclusions: the bourgeoisie and its collections of concepts}

By and large, the absence of 'dynasty' as well as related words to describe hereditary rule in the Geschichtliche Grundbegriffe was justified insofar as we can say that, with 
the exception of Max Weber's coinage of the term Erbcharisma, in German thought, each of these words were frequently used in a banal and not in a conceptual sense. However, when it comes to the term 'dynasty' itself, it is nonetheless striking how closely the German usage had remained to the original Greek concept of dynasty as a unique type of power abuse, usually by individuals, which can manifest itself in monarchies and democracies alike and which can also come about in revolutionary situations, throwing a sophisticated polity back into a more primitive state. This notion is less tied to hereditary charisma, as Weber's notion of Erbcharisma might suggest and as subsequent colloquial uses of the term 'dynasty' in the European languages might invite us to think.

The project of examining the range of meanings which German intellectuals attributed to notions of hereditary charisma as well as dynasty arguably also allows us to gain a fuller understanding of the mentality of this society. Not only words and conceptions, but also material artefacts and fictional plots, such as the collection of tankards in Spoelmann's glass assemblages, or Wagner's Ring Cycle, can be used to mine for contextualising conceptions of hereditary charisma. Weber, Simmel, Mann, and the glass collectors were all representatives of a bourgeois segment of late Wilhelmine society. This society was characterised by an espousal of liberal values, yet at the same time a pronounced fear of the dangers of modern democracy and nationalism. Prussian subjects, they were witnesses to a great change in German politics, away from the legacies of an imperial federation of cities and duchies - as seen above in the depiction of the tankards - towards a new, increasingly uniform nation under the aegis of a Prussian dynasty, the Hohenzollerns.

In the history of global modernity, looking at Germany allows us to engage with a highly 'self-conscious' experience of this process. As one of the world's leading 
economies, Germany enjoyed one of the strongest continued state investments in academic research, which continues to have global resonance today. It was also a gradually reforming constitutional monarchy and as such, one of the most advanced democracies of its time. German history in this period therefore offers much food for thought to those who are interested in modernity as a reflexive process. Intellectuals who trained and taught in German universities at the time offer a range of reflections on the process of modernisation itself, and their own status within it. I have explored one aspect of this intellectual culture, in which the preoccupation with conceptions of dynastic power were salient and yet a concept of 'dynasty' was strangely absent. By mining the uses of 'dynasty' in a range of ideal typical conceptions of political power among modern German thinkers we can obtain a more granular view of the way these self-consciously bourgeois thinkers reflected on notions of liberalism, democracy and modernity, and their own place in the progression of history which few of them were willing to call 'progress'. 


\section{Bibliography}

Aristotle, Politics, Book IV, ch. 5, 1292. Ed. Stephen Everson. Cambridge: Cambridge University Press, 1996.

Liddell, Henry George and Robert Scott. A Greek-English Lexicon. Oxford: Clarendon Press, 1940.

Assmann, Jan. Das kulturelle Gedächtnis: Schrift, Erinnerung und politische Identität in frühen Hochkulturen, 5th ed. Munich: Beck, 2005.

Aydin, Cemil. The Idea of the Muslim World. Cambridge, Mass.: Harvard University Press, 2017.

Bauschinger, Sigrid. Die Cassirers: Unternehmer, Kunsthändler, Philosophen:

Biographie Einer Familie. Munich: C.H. Beck, 2015.

Becker, Carl Heinrich. Islamstudien: Vom Werden Und Wesen Der Islamischen Welt, 2 vols. Leipzig: Quelle and Meyer, 1924.

Bergenthum, Hartmut. Weltgeschichten im Zeitalter der Weltpolitik: zur populären Geschichtsschreibung im wilhelminischen Deutschland. Munich: m-Press, 2004.

Brunner, Otto, Conze, Werner and Koselleck, Reinhart, eds., Geschichtliche

Grundbegriffe: Historisches Lexikon Zur Politisch-Sozialen Sprache in Deutschland, vo. 1 (Stuttgart: E. Klett, 1972).

Carey, Susan. The Origin of Concepts, 1. iss. Oxford Univ. paperback, Oxford Series in Cognitive Development (Oxford: Oxford Univ. Press, 2011).

Chernow, Ron. The Warburgs: The Twentieth-Century Odyssey of a Remarkable Jewish Family. New York, Vintage Books, 1994. 
Chiantera-Stutte, Patricia. 'Space, Großraum and Mitteleuropa in Some Debates of the Early Twentieth Century', European Journal of Social Theory 11, no. 2 (May 2008), $185-201$.

Chickering, Roger. Karl Lamprecht: A German Academic Life (1856-1915). Atlantic Highlands, NJ: Humanities Press, 1993.

Collins, Randall. Weberian Sociological Theory. Cambridge and New York: Cambridge University Press, 1986.

Conze, Werner and Jürgen Kocka, eds. Bildungssystem und Professionalisierung in internationalen Vergleichen, 2nd ed. Stuttgart: Klett-Cotta, 1992.

Damen Conversations-Lexikon, 10 vols., vol. 3. Leipzig : Comission Fr. Volckmar, 1834.

de Groot, Jan. The Religious System of China, Its Ancient Forms, Evolution, History and Present Aspect, Manners, Customs and Social Institutions Connected Therewith, 6 vols. Leiden: Brill, 1892-1910.

Dejung, Christof, David Motadel, and Jürgen Osterhammel. The Global Bourgeoisie: The Rise of the Middle Classes in the Age of Empire. Princeton: Princeton University Press, 2019.

Deutsches Staats-Wörterbuch, eds. Johann Caspar Bluntschli and Karl Brater. Stuttgart and Leipzig: Expedition des Staatswörterbuchs, 1857-70.

Handwörterbuch der Staatswissenschaften, eds. J. Conrad and W. Lexis, 4th ed. . Jena: Gustav Fischer, 1898.

Deutsches Wörterbuch von Jacob und Wilhelm Grimm, 16 vols. (Leipzig, 1854-1971), cited after the online edition, http://woerterbuchnetz.de/cgibin/WBNetz/call_wbgui_py from_form?sigle $=$ DWB\&mode $=$ Volltextsuche $\&$ firsthit $=0$ \&textpattern $=$ Dynastie \&lemmapattern $=\&$ patternlist $=\mathrm{T}:$ Dynastie $\&$ lemid $=\mathrm{GG} 23264 \&$ hit $\underline{\text { list }=12752922}$, accessed 11 October 2018. 
Duden, Die deutsche Rechtschreibung, 26 ${ }^{\text {th }}$ ed. Berlin: Dudenverlag, 2005. Accessed online, https://www.duden.de/suchen/dudenonline/Dynastie, 13 January 2019.

Ezcurdia, Maite. 'The Concept-Conception Distinction'. Philosophical Issues 9 (1998), 187.

Factor, Regis A.. Guide to the Archiv Für Sozialwissenschaft Und Sozialpolitik Group, 1904-1933: A History and Comprehensive Bibliography. New York: Greenwood Press, 1988.

Ferguson, Niall. Paper and Iron: Hamburg Business and German Politics in the Era of Inflation, 1897-1927. Cambridge, England; New York, NY, USA: Cambridge University Press, 1995.

Finger, Jürgen, Sven Keller, and Andreas Wirschin. Dr. Oetker Und Der Nationalsozialismus: Geschichte Eines Familienunternehmens 1933-1945. Munich:

C.H. Beck, 2013.

Finley, Moses. Ancient History: Evidence and Models. New York: Viking, 1986.

Fitzpatrick, Matthew P.. Liberal Imperialism in Germany: Expansionism and Nationalism, 1848-1884. New York: Berghahn Books, 2008.

Fontane, Theodor. Frau Jenny Treibel. Berlin: Fontane, 1893.

Gall, Lothar. Bürgertum, Liberale Bewegung Und Nation Ausgewählte Aufsätze. Berlin: Walter de Gruyter, 1997.

Gierke, Otto. 'Geschichte und Rechte Der Fideikommisse', Handwörterbuch Der Staatswissenschaften 3 (1892), 413-24.

Gizewski, Christian. 'Ein Heute Nötiger Rekonstruktionsversuch: Theodor Mommsens Römische Kaisergeschichte', Historische Zeitschrift, 259: 1 (January 1, 1994), 109-118. Gothein, Eberhard. Die badischen Markgrafschaften im 16. Jahrhundert. Heidelberg: Winter, 1910. 
Grassimuseum. Bildangaben: Reichsadlerhumpen Wohl Franken, 1672 Helles gelbgrünes Glas, frei geblasen, polychrome Emailbemalung Aufschrift: "Das Heilige

Römische / Reich mit sambt / Seinen Gliedern / 1672"

Höhe: 29,1 cm, Durchmesser: 13,8 cm Ankauf 1924. Ehemals Sammlung William

Davignon, Leipzig

Inv. Nr. 1924.47 Foto: Christoph Sandig, Leipzig.

Grosz, Georg. Der Spiesser-Spiegel [The Mirror of the Bourgeoisie] (c. 1925), available at https://www.tate.org.uk/art/artworks/grosz-drawing-for-the-mirror-of-thebourgeoisie-t00020, accessed 7 October 2018.

Habermas, Jürgen. Der philosophische Diskurs der Moderne: zwölf Vorlesungen Frankfurt am Main: Suhrkamp, 1985

Hall, Stuart. 'The Hinterland of Science: Ideology and the "Sociology of Knowledge"', in Centre for Contemporary Cultural Studies. On Ideology. London: Routledge, 1977, 933.

Handwörterbuch der Staatswissenschaften, hg. v. J. Conrad u. a., 3. Auflage, 2.

Supplementbd., Agrarverhältnisse im Altertum - Zinsfuß im Mittelalter, Jena (Gustav Fischer) 1897, S. 1-18.

Hanke, Edith. Max Weber in Zeiten des Umbruchs. Zur Aktualität und weltweiten Rezeption eines Klassikers, in: Max Weber in der Welt. Rezeption und Wirkung, hg. von der Max Weber Stiftung, bearbeitet von Michael Kaiser und Harald Rosenbach. Tübingen: Mohr Siebeck 2014, pp. 1-21.

Hegel, Georg Wilhelm Friedrich. Vorlesungen über die Philosophie der Geschichte. Leipzig: Reclam, 1924.

Hegel, Georg Wilhelm Friedrich. Vorlesungen über die Philosophie der Weltgeschichte I. Nachschriften zu dem Kolleg des Wintersemesters 1822/23. Ed. Bernadette Collenberg-Plotnikov. Hamburg: Meiner, 2015. 
Hegel, Georg Wilhelm Friedrich. Vorlesungen über die Philosophie der Religion.

Berlin: Duncker\& Humblot, 1832.

Helmholt, Hans Ferdinand, Weltgeschichte, 9 vols. Leipzig: Bibliographisches Institut, 1913-1922.

Herder's Conversations-Lexikon, vol. 2 Freiburg i. Br.: Herder'sche

Verlagsbuchhandlung, 1857.

Hübinger, Gangolf and Wolfgang J. Mommsen, eds., Intellektuelle Im Deutschen Kaiserreich, Originalausg. Frankfurt am Main: Fischer Taschenbuch Verlag, 1993.

Iggers, Georg G. 'The Historian Banished: Karl Lamprecht in Imperial Germany', Central European History, 27:1 (March 1994), 87.

James, Harold. Krupp: A History of the Legendary German Firm. Princeton: Princeton University Press, 2017.

Kant, Immanuel, Zum ewigen Frieden. Ein philosophischer Entwurf. Königsberg:

Friedrich Nicolovius, 1795, 22 ff. https://www.e-rara.ch/doi/10.3931/e-rara-25308, accessed 7 October 2018.

Köpf, Peter, Die Mommsens: Von 1848 Bis Heute-Die Geschichte Einer Familie Ist Die Geschichte Der Deutschen, Erstausg. Hamburg: Europa Verlag, 2004.

Kötzschke, Rudolf. Allgemeine Wirtschaftsgeschichte des Mittelalters. Jena: Fischer, 1924.

Koselleck, Reinhart. Historische Semantik und Begriffsgeschichte. Stuttgart: KlettCotta, 1979.

Lamprecht, Karl, Alte und neue Richtungen in der Geschichtswissenschaft (Leipzig: Gartners, 1896), and ,Problems of Universal History', in idem, What is history? Five lectures on the modern science of history. London and New York: Macmillan, 1905, 181-227. 
Lamprecht, Karl. Alte und neue Richtungen in der Geschichtswissenschaft (Leipzig: Gartners, 1896), and ,Problems of Universal History“, in idem, What is history? Five lectures on the modern science of history. London and New York: Macmillan, 1905, $181-227$.

Langewiesche, Dieter, ,Die ,Humboldtsche Universität‘ als nationaler Mythos. Zum Selbstbild der deutschen Universitäten in ihren Rektoratsreden im Kaiserreich und in der Weimarer Republik. Mommsen, 15 Oct 1874, Historische Zeitschrift, 290 (2010), 58.

Leonhard, Jörn. Der überforderte Frieden: Versailles und die Welt 1918-1923 (München: C.H.Beck, 2018).

Mangold-Will, Sabine, Eine 'weltbürgerliche Wissenschaft': die deutsche Orientalistik im 19. Jahrhundert. Stuttgart: Steiner, 2004.

Mann, Michael, ‘States, Ancient and Modern', European Journal of Sociology 18:2 (December 1977), 262-298.

Mann, Thomas, Königliche Hoheit. Berlin: S. Fischer, 1909. Cited after the edition Berlin: Deutsche Buchgemeinschaft, 1928, p. 314.

Marchand, Suzanne L., Down from Olympus: Archaeology and Philhellenism in Germany, 1750 - 1970. Princeton, NJ: Princeton University Press, 2003.

McCarty, Willard, 'Modeling: A Study in Words and Meanings', in A Companion to Digital Humanities, ed. Susan Schreibman, Ray Siemens, John Unsworth. Oxford: Blackwell, 2004.

http://www.digitalhumanities.org/companion/view?docId=blackwell/9781405103213/9 781405103213.xml\&chunk.id=ss1-3-7, accessed 7 October 2018 
McDaniel, Iain, 'The Politics of Historical Economics: Wilhelm Roscher on

Democracy, Socialism and Caesarism', Modern Intellectual History, 15:1 (April 2018), $93-122$.

Meeks, Elijah and Scott D. Weingart, 'The Digital Humanities Contribution to Topic Modeling', Journal of Digital Humanities, 2:1 (2012), 2-6.

Meinecke, Friedrich. Die Idee der Staatsräson in der Neueren Geschichte. Munich and Berlin: Oldenbourg, 1925.

Meinecke, Friedrich, 'Die geschichtlichen Ursachen der deutschen Revolution', in idem, Nach der Revolution. Geschichtliche Betrachtungen über unsere Lage. Munich and Berlin: Oldenbourg, 1919.

Meinecke, Friedrich, Weltbürgertum und Nationalstaat. Munich and Berlin:

Oldenbourg, 1908, 2nd ed. 1911.

Meinecke, Friedrich, 'Verfassung und Verwaltung der deutschen Republik', in Die Neue Rundschau, 30 (January 1919), 1-16.

Meyer, Eduard, Geschichte des Altertums, 9 vols. Stuttgart and Berlin: Cotta, 18841907, vol. 2 .

Middell, Matthias. Weltgeschichtsschreibung im Zeitalter der Verfachlichung und Professionalisierung. Das Leipziger Institut für Kultur- und Universalgeschichte 18901990, 3 vols. Leipzig: Akademische Verlagsanstalt, 2005.

Mimno, David, 'Computational Historiography: Data Mining in a Century of Classics Journals', Journal on Computing and Cultural Heritage 5, no. 1 (1 April 2012), 1-19. Mommsen, Theodor. Römische Geschichte I-III. Leipzig 1854-56), and idem, Römisches Staatsrecht, vols. I and II. Leipzig: S. Hirzel, 1876.

Mommsen, Theodor, Römisches Staatsrecht Leipzig: Samuel Hirzel, 1876. 
Mommsen, Theodor, Wenn Toren aus der Geschichte falsche Schlüsse ziehen: ein Theodor-Mommsen-Lesebuch, ed. Wilfried Nippel, dtv Bibliothek. Munich: dtv, 2017 Mommsen, Wolfgang J., Bürgerliche Kultur Und Künstlerische Avantgarde: Kultur Und Politik Im Deutschen Kaiserreich 1870 Bis 1918, Propyläen-Studienausgabe. Frankfurt am Main, Berlin: Ullstein ; Propyläen, 1994.

Mosse, George L., The Crisis of German Ideology: Intellectual Origins of the Third Reich, 1st H. Fertig pbk. ed New York: H. Fertig, 1998.

Naumann, Friedrich, Demokratie und Kaisertum : ein Handbuch für innere Politik Berlin-Schöneberg: die „Hilfe“, 1904.

Nietzsche, Friedrich, 'On the uses and disadvantages of history for life', in Untimely Meditations, trans. R. J. Hollingdale. Cambridge: Cambridge University Press, 1983, $57-125$.

Nietzsche, Friedrich, Der Fall Wagner (1888). Leipzig: F. Kröner, 1919.

Nietzsche, Friedrich, Zur Genealogie der Moral (Leipzig: Naumann, 1887), passim, and Jenseits von Gut und Böse Leipzig: Naumann, 1886, part V Aphorism 200.

Oexle, Otto Gerhard, ed., Memoria als Kultur.Göttingen: Vandenhoeck \& Ruprecht, 1995, Introduction, 1-69.

Oexle, Otto Gerhard, 'Aspekte der Geschichte des Adels im Mittelalter und in der Frühen Neuzeit', in Hans-Ulrich Wehler ed., Europäischer Adel, 1750-1950. Göttingen: Vandenhoeck \& Ruprecht, 1990, 19-56.

Onken, Wilhelm, Das Zeitalter des Kaisers Wilhelm, 2 vols. Berlin: G. Grote'sche Verlagsbuchhandlung, 1890.

Osterhammel, Jürgen, 'Gesellschaftsgeschichtliche Parameter Chinesischer Modernität', Geschichte und Gesellschaft, 28:1 (March 2002), 71-108.

Oxford English Dictionary. Oxford: Oxford University Press, 1897. Oxford Living Dictionary, https://www.oxforddictionaries.com/oed 
Rebenich, Stefan, Theodor Mommsen, and Adolf von Harnack, Theodor Mommsen Und Adolf Harnack: Wissenschaft Und Politik Im Berlin Des Ausgehenden 19.

Jahrhunderts: Mit Einem Anhang, Edition Und Kommentierung Des Briefwechsels Berlin: De Gruyter, 1997, 327 ff.

Ringer, Fritz, The Decline of the German Mandarins: The German Academic

Community, 1890-1933 Hanover: University Press of New England, 1990.

Roscher, Wilhelm, 'Umrisse Zur Naturlehre Der Drei Staatsformen', Allgemeine Zeitschrift Für Geschichtswissenschaft 7 (1847): 79-88, 322 ff. and 436ff., 461.

Roscher, Wilhelm, 'Umrisse zur Naturlehre des Cäsarismus', Abhandlungen der Königlich Sächsischen Gesellschaft der Wissenschaften, 10 (1888), 641-753.

Rosenberg, Hans, Grosse Depression und Bismarckzeit: Wirtschaftsablauf, Gesellschaft und Politik in Mitteleuropa Berlin: Walter de Gruyter, 1967.

Sachse, Wieland, 'Familienunternehmen in Wirtschaft Und Gesellschaft Bis Zur Mitte

Des 20. Jahrhunderts.Ein Historischer Überblick', Zeitschrift Für

Unternehmensgeschichte / Journal of Business History 1 (1991): 9-25

Scaff, Lawrence A., 'Weber on the Cultural Situation of the Modern Age', in The Cambridge Companion to Weber, ed. Stephen Turner. Cambridge: Cambridge University Press, 2000, 99-116.

Schlegel, August Wilhelm von, „Wechsel der Dynastie in den Philosophenschulen“, Sämtliche Werke, Vol. 2, Leipzig: Weidmann'sche Buchhandlung, 1846, 231.

Schmitt, Carl, Völkerrechtliche Grossraumordnung mit Interventionsverbot für raumfremde Mächte. Ein Beitrag zum Reichsbegriff im Völkerrecht.

Schramm, Percy Ernst, Herrschaftszeichen und Staatssymbolik. Beiträge zu ihrer Geschichte vom dritten bis zum sechzehnten Jahrhundert. 5 vols. Stuttgart: Hiersemann, 1954-1978. 
Schönpflug, Daniel, Die Heiraten Der Hohenzollern: Verwandtschaft, Politik Und Ritual in Europa, 1640-1918, Kritische Studien Zur Geschichtswissenschaft, Vol. 207 Göttingen: Vandenhoeck \& Ruprecht, 2013.

Schumpeter, Joseph, ,Unternehmer', In Ludwig Elster, Adolf Weber, Friedrich Wieser (eds.) Handwörterbuch der Staatswissenschaften, Vol. 8, 4th ed. (Jena: Gustav Fischer, 1928), pp. $476-487$.

Sewell, William, 'A Strange Career: The Historical Study of Economic Life', History and Theory, 49:4 (December 2010), 146-66.

Sheehan, James J., 'Deutscher Liberalismus Im Postliberalen Zeitalter 1890-1914', Geschichte Und Gesellschaft, 4:1 (1 January 1978), 29-48.

Simmel, Georg, 'Soziologie Der Über- Und Unterordnung', Archiv Für Sozialwissenschaft Und Sozialpolitik 24, no. 3 (n.d.): 477-546.

Simmel, Georg, Soziologie. Untersuchungen Über Die Formen Der Vergesellschaftung Leipzig: Duncker \& Humblot, 1908.

Sombart, Werner, Der Bourgeois: Zur Geistesgeschichte Des Modernen Wirtschaftsmenschen .Munich and Leipzig: Duncker \& Humblot, 1913. Spengler, Oswald, Der Untergang des Abendlandes, 2 vols. Munich: C.H. Beck, 1918, 1921.

Staats- und Gesellschafts-Lexikon: neues Conversations-Lexikon, ed. Friedrich Wilhelm Hermann Wagener, 23 vols. Berlin: F. Heinicke, 1859-67.

Staub, Martial, 'Bürgerlichkeit im Exil: Bernhard Groethuysen und Hans Baron', in Nationalsozialismus in den Kulturwissenschaften, vol. 2, eds. Hartmut Lehmann and Otto- Gerhard Oexle, Göttingen: Vandenhoeck \& Ruprecht, 2004. 351-64. Stubbes, William, English Constitutional History from the Earliest Times to the reign of Edward the First, vol. 1 Oxford: Clarendon Press, 1913. 
Stuckey, Mary, 'Dynasties and Democracy', Rhetoric and Public Affairs, 20: 3 (2017), 539-44; and Eric Nelson, The Royalist Revolution: Monarchy and the American Founding Cambridge, MA: Belknap Press, 2014.

Voltaire, Anti Machiavel ou Essai du critique de Machiavel Paris : Pierre Paupie, 1740. von Pflugk-Harttung, Julius (ed.), Weltgeschichte. Die Entwicklung der Menschheit in Staat und Gesellschaft, 6 vols. Berlin: Ullstein, 1907-11.

Wagner, Richard, Der Ring der Nibelungen. Ein Bühnenfestspiel für drei Tage und einen Vorabend. Leipzig: Fikentscher Verlag, 1935.

Wagner, Richard, Die Nibelungen. Weltgeschichte aus der Sage. Leipzig: Insel, 1914. Weber, Max et al., Die Wirtschaftsethik Der Weltreligionen: Schriften 1915-1920. Konfuzianismus Und Taoismus, Gesamtausgabe / Max Weber. Abt. I, Schriften Und Reden, Volol. 21 Halbbd. 2: Schriften und Reden Die Wirtschaftsethik der Weltreligionen: das antike Judentum; Schriften und Reden 1911 - 1920 [...]Tübingen: Mohr Siebeck, 2005.

Weber, Max, 'Deutschlands Künftige Staatsform', in Zur Neuordnung Deutschlands. Schriften Und Reden 1918-1920, Mommsen, Wolfgang and Schwentker, Wolfgang, vol. 16, Max Weber Gesamtausgabe. Tübingen: Mohr Siebeck, 1988, 98-146.

Weber, Max, 'Deutschlands Politische Neuordnung [Bericht Der Münchener Neuesten Nachrichten]', in Zur Neuordnung Deutschlands. Schriften Und Reden 1918-1920 eds. Wolfgang Mommsen and Wolfgang Schwentker. Tübingen: Mohr Siebeck, 1988.

Weber, Max, ‘Die Objektivität Sozialwissenschaftlicher Und Sozialpolitischer Erkenntnis', Archiv Für Sozialwissenschaft Und Sozialpolitik 19, no. 1 (1904), 22-87. Weber, Max, ,Agrarverhältnisse im Altertum', in Handwörterbuch der Staatswissenschaften, ed. J. Conrad. Jena: Gustav Fischer, 1897, 1-16. 
Weber, Max, ,Agrarverhältnisse im Altertum', in Handwörterbuch der

Staatswissenschaften, eds. J. Conrad and W. Lexis, Vol. 1 Jena: Gustav Fischer, 1898, $57-85,60$

Weber, Max, Das neue Deutschland. Bericht des Wiesbadener Tagblatts. 389-90.

Weber, Max, Deutschlands künftige Staatsform, MWG 99. Sonderdruck Frankfurter Zeitung 1919. Five articles in Frankfurter Zeitung.

Weber, Max, Deutschlands Wiederaufrichtung. Bericht der Heidelberger Neuesten Nachrichten. MWG 415.

Weber, Max, Die römische Agrargeschichte in ihrer Bedeutung für das Staats-und Privatrecht. Stuttgart: Ferdinand Enke, 1891.

Weber, Max, Die Römische Agrargeschichte in ihrer Bedeutung für Staats- und Privatrecht. 1891.

Weber, Max, Konfuzianismus und Taoismus, Section II on the feudal state.

Weber, Max, Wirtschaft Und Gesellschaft: Soziologie: Unvollendet, 1919-1920, Gesamtausgabe. Abteilung I, Schriften Und Reden / Max Weber, Vol. 23, eds. Knut Borchardt, Edith Hanke and Wolfgang Schluchter. Tübingen: J.C.B. Mohr Siebeck, 2013, 504-509.

Weber, Max, Zur Geschichte der Handelsgesellschaften im Mittelalter. Nach südeuropäischen Quellen. Stuttgart: Ferdinand Enke, 1889.

Weber, Max, Zur Sozial- und Wirtschaftsgeschichte des Altertums, ed. Jürgen Deininger, in Max-Weber-Gesamtausgabe I/6. Tübingen: Mohr/Siebeck, 2006. Weber, Max. Wirtschaft und Gesellschaft. Hgs. Edith Hanke, Thomas Kroll. MaxWeber-Gesamtausgabe. Tübingen: Mohr, 2005, 170.

Wehler, Hans-Ulrich, Das Deutsche Kaiserreich, 1871-1918, Vol. 9 Göttingen: Vandenhoeck und Ruprecht, 1977 
Wellhausen, Julius, Das Arabische Reich und Sein Sturz. Berlin: Georg Reimer, 1902.

Ziemann, Benjamin, Das Deutsche Kaiserreich 1871-1918 . Bonn: Bundeszentrale für

Politische Bildung, 2016.

Walsh, John, 'The Concept of "Dunasteia" in Aristotle and the Macedonian Monarchy', Acta Classica 57 (2014): 165-83.

Cartledge, Paul. Ancient Greek Political Thought in Practice, Key Themes in Ancient History. Cambridge and New York: Cambridge University Press, 2009.

Plato, Laws, ed. Malcolm Schofield, and Tom Griffith, Cambridge Texts in the History of Political Thought. Cambridge and New York: Cambridge University Press, 2016.

1 ,Dynasty“, Oxford English Dictionary (1897); see also entry in Oxford Living Dictionaries, https://www.oxforddictionaries.com/oed, accessed 13 January 2019. 'Dynastie', defined as 'Herrschergeschlecht', in Duden.

${ }^{2}$ Brunner, Conze, and Koselleck, eds., Geschichtliche Grundbegriffe.

${ }^{3}$ Koselleck, Historische Semantik und Begriffsgeschichte, 29.

${ }^{4}$ On intellectual culture in the Kaiserreich, see Hübinger and Mommsen (eds.), Intellektuelle im Deutschen Kaiserreich. On the evolution of German national liberalism in this context, see Gall, Bürgertum; Sheehan, 'Deutscher Liberalismus Im Postliberalen Zeitalter 1890-1914'; and Fitzpatrick, Liberal Imperialism in Germany.

${ }^{5}$ For the longer debate, see, for instance, Carey, The Origin of Concepts. For the distinction I make here between concepts and conceptions, see Ezcurdia, 'The Concept-Conception Distinction'.

${ }^{6}$ For a classic work on Realienkunde, see Percy Ernst Schramm, Herrschaftszeichen und Staatssymbolik. Beiträge zu ihrer Geschichte vom dritten bis zum sechzehnten Jahrhundert. Thanks to Martial Staub for drawing my attention to Realienkunde.

${ }^{7}$ Deutsches Wörterbuch von Jacob und Wilhelm Grimm.

${ }^{8}$ Deutsches Staats-Wörterbuch, eds. Bluntschli and Brater; Handwörterbuch der Staatswissenschaften, eds. J. Conrad and W. Lexis, 4th ed. See also Staats- und Gesellschafts-Lexikon: neues Conversations-Lexikon, ed. Wagener.

${ }^{9}$ Herder's Conversations-Lexikon, vol. 2, 482; Damen Conversations-Lexikon, vol. 3 (1834), 245.

${ }^{10}$ For helpful discussions of dynastic power in historical contexts and in political thought, see Mann,

'States, Ancient and Modern', 262; Schönpflug, Die Heiraten Der Hohenzollern; and Osterhammel,

'Gesellschaftsgeschichtliche Parameter Chinesischer Modernität'.

${ }^{11}$ Kant, Zum ewigen Frieden.

${ }^{12}$ See, for instance, the discussion Marchand, Down from Olympus.

${ }^{13}$ August Wilhelm von Schlegel, ,Wechsel der Dynastie in den Philosophenschulen', in Sämtliche Werke, Vol. 2, Leipzig 1846, 231.

${ }^{14}$ Hegel, Philosophie der Religion, 179, 246, 254 and passim.

${ }^{15}$ Hegel, Vorlesungen über die Philosophie der Geschichte, 66, 222, 229. ,Weil Deutschland ein

Wahlreich war, deswegen ist es nicht ein Staat geworden, und aus demselben Grunde ist Polen aus der

Reihe der selbständigen Staaten verschwunden.', 66.

16 Ibid, 229.

${ }^{17}$ Cf. Nietzsche, Zur Genealogie der Moral, part V Aphorism 200.

${ }^{18}$ Nietzsche, 'On the uses and disadvantages of history for life', 60.

${ }^{19}$ Nietzsche, Der Fall Wagner,

${ }^{20}$ Wagner, Die Nibelungen, 3 and passim; Wagner, Ring-Libretto, 28 and passim. From Rhinegold: 
Fasolt to Wotan

Höhn'st du uns? ha, wie unrecht!

Die ihr durch Schönheit herrscht,

schimmernd hehres Geschlecht,

wir thörig strebt ihr nach Thürmen von Stein,

setzt um Burg und Saal

Weibes Wonne zum Pfand!

You are mocking us? oh, how unjustly!

You who rule by beauty,

sublimely beautiful race,

how futile is your striving for towers and stones

as with each castle and hall

You are pledging the pleasures of womankind!

${ }^{21}$ Weber, Wirtschaft Und Gesellschaft, 504-509.

${ }^{22}$ On Weber's use of ideal types, see Weber, 'Die Objektivität Sozialwissenschaftlicher und

Sozialpolitischer Erkenntnis'.

${ }^{23}$ Hall, 'The Hinterland of Science'.

${ }^{24}$ Sewell, 'A Strange Career: The Historical Study of Economic Life'.

${ }^{25}$ For some classic examples, see Ringer, The Decline of the German Mandarins; Mosse, The Crisis of

German Ideology; Habermas, Der philosophische Diskurs der; and Collins, Weberian Sociological

Theory. For a broader view of the period, see Mommsen, Bürgerliche Kultur und Künstlerische

Avantgarde, and Aldenhoff, Hübinger, and Mommsen, eds. Intellektuelle Im Deutschen Kaiserreich.

${ }^{26}$ There has been growing interest recently in a fresh look at the Kaiserreich, including Ziemann, Das

Deutsche Kaiserreich 1871-1918.

${ }^{27}$ See Edith Hanke, ,Max Weber in Zeiten des Umbruchs'. See also Martial Staub, 'Bürgerlichkeit im Exil: Bernhard Groethuysen und Hans Baron'.

${ }^{28}$ Cf. Factor, Guide to the Archiv Für Sozialwissenschaft und Sozialpolitik Group, 1904-1933.

${ }^{29}$ For a classic analysis of this period as a whole, see the contemporary account by Oncken, Das Zeitalter des Kaisers Wilhelm, 2 vols. See also Wehler, Das Deutsche Kaiserreich, 1871-1918.

${ }^{30}$ Rosenberg, Grosse Depression und Bismarckzeit.

${ }^{31}$ Fontane, Frau Jenny Treibel, 173.

${ }^{32}$ On the construction of the ethos of an aristocratic family in Europe and particularly the use of lineages in this context, see Otto Gerhard Oexle, 'Aspekte der Geschichte des Adels im Mittelalter und in der Frühen Neuzeit'.

${ }^{33}$ See also Conze and Kocka, eds., Bildungssystem und Professionalisierung in internationalen

Vergleichen. On the most characteristic portraits of the bourgeoise in this period, see Fontane, Frau Jenny Treibel; and Sombart, Der Bourgeois: Zur Geistesgeschichte Des Modernen Wirtschaftsmenschen. For a visual caricature of the later end of the period under discussion, see the work of Georg Grosz, Der Spiesser-Spiegel [The Mirror of the Bourgeoisie] (c. 1925), available at https://www.tate.org.uk/art/artworks/grosz-drawing-for-the-mirror-of-the-bourgeoisie-t00020, accessed 7 October 2018.

${ }^{34}$ Mann, Königliche Hoheit, ,Imma‘. Cited after the edition Berlin: Deutsche Buchgemeinschaft, 1928, p. 314.

${ }^{35}$ Information thanks to Katharina Nitsch, Grassimuseum. Bildangaben:

Reichsadlerhumpen Wohl Franken, 1672 Helles gelbgrünes Glas, frei geblasen, polychrome

Emailbemalung Aufschrift: "Das Heilige Römische / Reich mit sambt / Seinen Gliedern / 1672"

Höhe: 29,1 cm, Durchmesser: 13,8 cm Ankauf 1924. Ehemals Sammlung William Davignon, Leipzig Inv. Nr. 1924.47 Foto: Christoph Sandig, Leipzig.

${ }^{36}$ Simmel, Soziologie, 160.

${ }^{37}$ On conceptual models, particularly in economic history, see Finley, Ancient History, 61.

${ }^{38}$ On the older tradition, see Marchand, Down from Olympus. On the academic study of comparative history in late imperial Germany, see the work of Karl Lamprecht - as a teacher, not as an author - stands out. Lamprecht, Alte und neue Richtungen in der Geschichtswissenschaft. See also Chickering, Roger, Karl Lamprecht: A German Academic Life; and a review by Georg G. Iggers, 'The Historian Banished: Karl Lamprecht in Imperial Germany', Central European History, 27:1 (March 1994), 87.

${ }^{39}$ On popular publications in global history, see the work by the head of the Prussian State Secret

Archives, von Pflugk-Harttung (ed.), Weltgeschichte; Helmholt, Weltgeschichte, 9 vols. (Leipzig: Bibliographisches Institut, 1913-1922), and Spengler, Der Untergang des Abendlandes, 2 vols. (Munich: C.H. Beck,1918, 1921). On the institutional history of German world history, see Middell, 
Weltgeschichtsschreibung im Zeitalter der Verfachlichung und Professionalisierung, and Bergenthum, Weltgeschichten im Zeitalter der Weltpolitik: zur populären Geschichtsschreibung im wilhelminischen Deutschland, Forum deutsche Geschichte 4 (München: m-Press, 2004).

${ }^{40}$ Scaff, 'Weber on the Cultural Situation of the Modern Age'. Weber, Die römische Agrargeschichte in ihrer Bedeutung für das Staats-und Privatrecht; see also Weber, ,Agrarverhältnisse im Altertum', in Handwörterbuch der Staatswissenschaften, eds. Conrad andLexis, Vol. 1; Weber et als., Die Wirtschaftsethik Der Weltreligionen: Schriften 1915-1920. Konfuzianismus Und Taoismus, in Gesamtausgabe; Weber, Abt. I, Schriften Und Reden, Vol. 1, 21 Halbbd. 2: Schriften und Reden. Die Wirtschaftsethik der Weltreligionen.

${ }^{41}$ Weber, Wirtschaft und Gesellschaft, 170.

${ }^{42}$ Ibid, Section I A., ,Stadt, Fürst und Gott'.

43 „Die erbcharismatische Stellung der (in vielem noch sehr hypothetischen) »Dynasten« im frühesten deutschen Mittelalter würde den chinesischen Verhältnissen am ehesten entsprechen. Aber in den Kerngebieten des westlichen Feudalismus war unter dem Umsturz der traditionalen Rangordnungen durch die Eroberung und Wanderung offenbar das feste Gefüge der Sippen stark gelockert, und die Kriegsnotwendigkeiten erzwangen gebieterisch die Aufnahme jedes tüchtigen, militärisch geschulten, Mannes in die Ritterschaft, also: die Zulassung jedes ritterlich Lebenden zur Ritterwürde. Erst die weitere Entwicklung führte dann zum Erbcharisma, schließlich zur »Ahnenprobe«. In China war dagegen das Erbcharisma der Sippe - in der für uns zugänglichen Zeit - stets das Primäre (mindestens der Theorie nach $\stackrel{83}{ }$; erfolgreiche Parvenus hat es immer gegeben)." Weber, Konfuzianismus und Taoismus, Section II on the feudal state.

${ }^{44}$ Ibid, Section V ,Der Literatenstand‘.

${ }^{45}$ Weber, , Das antike Judentum', 517.

${ }^{46}$ Weber, ,Agrarverhältnisse im Altertum', in Handwörterbuch der Staatswissenschaften. Weber, MaX, Zur Sozial- und Wirtschaftsgeschichte des Altertums, ed. Deininger, in Max-Weber-Gesamtausgabe I/6 (Tübingen: Mohr/Siebeck), 2006; and also Theodor Mommsen, Römische Geschichte I-III and Römisches Staatsrecht, vols. I and II.

${ }^{47}$ Weber, Agrarverhältnisse im Altertum, 7. Grundlagen der Entwicklung in der Kaiserzeit. First in Handwörterbuch der Staatswissenschaften, hg. v. J. Conrad u. a., 3. Auflage, 2. Supplementbd., Agrarverhältnisse im Altertum - Zinsfuß im Mittelalter, Jena (Gustav Fischer) 1897, S. 1-18.

${ }^{48}$ Cf. Meyer, Geschichte des Altertums, 9 vols., vol. 2, Section 1: ,Das Eingreifen Babyloniens. Die Assyrer in Kappadokien und die vorderasiatische Gesamtkultur'. On Eduard Meyer's interpretation of dynastic succession, see Jan Assmann, Das kulturelle Gedächtnis: Schrift, Erinnerung und politische Identität in frühen Hochkulturen.

${ }^{49}$ Meyer, Geschichte des Altertums, 9 vols. (Stuttgart and Berlin: Cotta, 1884-1907), vol. 2, 'Ramses' III. Ausgang. Die späteren Ramessiden. Niedergang Ägyptens'.

${ }^{50} \mathrm{Cf}$. Lamprecht, Alte und neue Richtungen in der Geschichtswissenschaft, and idem, Problems of Universal History', in idem, What is history? Five lectures on the modern science of history (London and New York: Macmillan, 1905), 181-227.

${ }^{51}$ On Mommsen's liberalism in its time, see Mommsen, Wenn Toren aus der Geschichte falsche Schlüsse ziehen, ed. Wilfried Nippel, dtv Bibliothek.

52 Mommsen, Theodoro. Römisches Staatsrecht (Leipzig: Samuel Hirzel, 1876). Christian Gizewski, 'Ein Heute Nötiger Rekonstruktionsversuch'.

${ }^{53}$ On Mommsen who never wrote imperial history and his liberalism, see Mommsen, Wenn Toren aus der Geschichte falsche Schlüsse ziehen: ein Theodor-Mommsen-Lesebuch, ed. Wilfried Nippel, dtv Bibliothek. München: dtv, 2017, See also Rebenich, Mommsen, and Harnack, Theodor Mommsen Und Adolf Harnack: Wissenschaft Und Politik Im Berlin Des Ausgehenden 19. Jahrhunderts: Mit Einem Anhang, Edition Und Kommentierung Des Briefwechsels (Berlin: De Gruyter, 1997), 327 ff.

${ }^{54}$ Wellhausen, Das Arabische Reich und Sein Sturz; Becker, Carl Heinrich, Islamstudien: Vom Werden Und Wesen Der Islamischen Welt, 2 vols. Leipzig: Quelle and Meyer, 1924, vol. 2, 27 on the African dynasties, 443, on the end oft he Osmans. On the idea of the Muslim world as a geopolitical construct in the context of the First World War, see Aydin, The Idea of the Muslim. See also Sabine Mangold-Will, Eine 'weltbürgerliche Wissenschaft': die deutsche Orientalistik im 19. Jahrhundert, Pallas Athene 11 (Stuttgart: Steiner, 2004).

${ }^{55}$ On Oexle's discussion of memoria, cf. Otto Gerhard Oexle ed., Memoria als Kultur. I am grateful to Martial Staub for his suggestion to review Oexle's work in this context.

${ }^{56}$ Cf. Gothein, Die badischen Markgrafschaften im 16. Jahrhundert. One exception is Kötzschke, Allgemeine Wirtschaftsgeschichte des Mittelalters, 307.

57 Simmel, Soziologie; Simmel, Georg, 'Soziologie Der Über- Und Unterordnung', Archiv Für Sozialwissenschaft Und Sozialpolitik 24, no. 3 (n.d.): 477-546. 
${ }^{58}$ Simmel, Soziologie, 181. On Stubbs' use of the term 'dynasty', see Stubbs, English Constitutional History from the Earliest Times to the reign of Edward the First, vol. 1, on revolution and the recognition of a new dynasty, ch. XVIII on the houses of Lancaster and York and the issue of dynasty, esp. 11 on the succession of the house of Lancaster.

${ }^{59}$ Weber, Max, Zur Geschichte der Handelsgesellschaften im Mittelalter. Nach südeuropäischen Quellen (Stuttgart: Ferdinand Enke, 1889).

${ }^{60}$ Weber, Max, Die Römische Agrargeschichte, 1891.

${ }^{61}$ Gierke, 'Geschichte und Rechte Der Fideikommisse', 413-24, 422.

${ }^{62}$ Cf. Joseph Schumpeter, ,Unternehmer',In Handwörterbuch der Staatswissenschaften, Vol. 8, 4th ed. (Jena: Gustav Fischer, 1928), pp. 476 - 487.

${ }^{63}$ On dynasty and American political thought, see Mary Stuckey, 'Dynasties and Democracy'; and Eric Nelson, The Royalist Revolution: Monarchy and the American Founding.

${ }^{64} \mathrm{Cf}$. Sachse, 'Familienunternehmen in Wirtschaft Und Gesellschaft Bis Zur Mitte Des 20.

Jahrhunderts.Ein Historischer Überblick'; Chernow, The Warburgs; Ferguson, Paper and Iron: Hamburg

Business and German Politics in the Era of Inflation, 1897-1927; Köpf, Die Mommsens.

${ }^{65}$ Cf. Bauschinger, Die Cassirers: Unternehmer, Kunsthändler, Philosophen.

${ }^{66}$ James, Krupp: A History of the Legendary German Firm; Finger, Keller, and Wirsching, Dr. Oetker Und Der Nationalsozialismus.

${ }^{67}$ Voltaire, Anti Machiavel ou Essai du critique de Machiavel (Paris : Pierre Paupie, 1740) ; see also the discussion in Meinecke, Die Idee der Staatsräson.

${ }^{68}$ On this point, see Meinecke, Idee, 327.

${ }^{69}$ Voltaire, Anti Machiavel ou Essai du critique de Machiavel.

${ }^{70}$ Meinecke, Weltbürgertum und Nationalstaat, $85 \mathrm{n} 2$.

${ }^{71}$ Ibid, 239

72 On the self-representation of the Hohenzollerns as a globally connected dynasty, see Schönpflug, Das Heiraten der Hohenzollern, 254-72.

${ }^{73}$ Ibid, 334 and 362.

74 Ibid, 453 and 498.

${ }^{75}$ Langewiesche, ,Die ,Humboldtsche Universität‘ als nationaler Mythos.

${ }^{76}$ Mcdaniel, 'The Politics of Historical Economics: Wilhelm Roscher on Democracy, Socialism and Caesarism'. See also Roscher, 'Umrisse zur Naturlehre des Cäsarismus'.

${ }^{77}$ Roscher, 'Umrisse Zur Naturlehre Der Drei Staatsformen'.

${ }^{78}$ Ibid, 15.

${ }^{79}$ Michels, Parteiwesen. 216

${ }^{80}$ Ibid, 236-37.

${ }^{81}$ Ibid, 238.

${ }^{82}$ Ibid, 252.

${ }^{83}$ Naumann, Demokratie und Kaisertum. On Mitteleuropa and empire, see the notorious work by Schmitt, Völkerrechtliche Grossraumordnung mit Interventionsverbot für raumfremde Mächte; Chiantera-Stutte, 'Space, Großraum and Mitteleuropa in Some Debates of the Early Twentieth Century';

${ }^{84}$ On the global context of anti-dynastic sentiment in 1918, see Leonhard, Der überforderte Frieden.

${ }^{85}$ Weber, 'Deutschlands Politische Neuordnung [Bericht Der Münchener Neuesten Nachrichten]'; Weber, Max, 'Deutschlands Künftige Staatsform'.

${ }^{86}$ Weber, ,Deutschlands künftige Staatsform‘, MWG 99.

${ }^{87}$ Ibid, 112.

${ }^{88}$ Ibid, 128.

${ }^{89}$ MWG 372-3.

${ }^{90}$ Weber, ,Das neue Deutschland. Bericht des Wiesbadener Tagblatts'.

91 ,Deutschlands Wiederaufrichtung. Bericht der Heidelberger Neuesten Nachrichten`.

${ }^{92}$ Meinecke, 'Die geschichtlichen Ursachen der deutschen Revolution', 18.

${ }^{93}$ Meinecke, 'Die geschichtlichen Ursachen der deutschen Revolution', 18.

${ }^{94}$ Cf. Aristotle, Politics, Book IV, ch. 5, 1292 and 1293a. Elsewhere, he also identifies revolutions as particularly conducive to the emergence of dynastic forms of tyranny. For a wider range of ancient authors, see the entry in Liddell and Scott, A Greek-English Lexicon.

${ }^{95}$ Plato, Laws, III, 680 b. For the wider context, see Cartledge, Ancient Greek Political Thought; Walsh, 'The Concept of "Dunasteia" in Aristotle and the Macedonian Monarchy'. 